Leonid Dvorkin ${ }^{1}$, Lyudmila Nihaeva ${ }^{1}$

${ }^{1}$ National University of Water and Environmental Engineering, Rivne, Ukraine
Scientific paper

ISSN 0351-9465, E-ISSN 2466-2585

UDC:666.943.4:666.9.015.66:666.9.017

https://doi.org/10.5937/zasmat2104340D

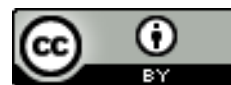

Zastita Materijala 62 (4)

$340-348$ (2021)

\title{
Modified supersulfated cements
}

\begin{abstract}
The paper presents the results of experimental studies of the possibility of obtaining modified supersulfate cements (SSC) with improved physical and mechanical properties on lowalumina blast-furnace granular slags. It has been shown in comparative experimental tests of the effect of admixtures of various sulfate activators that the highest strength of cements is achieved when using a phosphogypsum neutralized with lime. An additional activating effect has been established for supersulfated cements with the introduction of admixtures fluorides and, in particular, fluorides of magnesium, calcium and sodium silicofluoride. The additional introduction of hardening accelerators and their compositions with a superplasticizer into the SSC composition makes it possible to increase the compressive strength of cements at 28 days of age up to 60-65 MPa while achieving high strength at an early age.

Along with standard tests, experiments were performed using mathematical planning with obtaining adequate regression equations.

Key words: blast furnace slag, sulfate activators, phosphogypsum, hardening accelerators, superplasticizer, lime, supersulfated cement, properties.
\end{abstract}

\section{INTRODUCTION}

Highly ecological and energyefficient materials include clinker-free slag binders. This group, along with lime-slag and slag-alkaline, includes supersulfated cements (SSC) known also as gypsum slag cements. The hardening of these cements, based on sulfate activation of granulated blast-furnace slags (GBFS) with the formation of an artificial stone, is achieved by the introduction of special activator admixtures. They provide the destruction of slags, depolymerization of the silicon-oxygen tetrahedra included in them and the formation of new hydrate phases [1].

The most studied and implemented in practice are alkaline methods of activating GBFS. Alkaline activation is achieved by using lime and cement,

${ }^{*}$ Corresponding author: Leonid Dvorkin

E-mail: dvorkin.leonid@gmail.com

Paper received: 17. 09. 2021.

Paper accepted: 29. 09. 2021.

Paper is available on the website: www.idk.org.rs/journal when hydrated which is released calcium hydroxide, also sodium and potassium compounds, which form a highly alkaline medium when dissolved in water [2].

The first report on the possibility of obtaining cement from blast-furnace slag and gypsum was made by H.Kuhl in 1908 (German Pat. 237777). According to this patent, SSC can be obtained by adding more than 2\% gypsum to blast-furnace slag. Further research carried out by R. Grun, P. Budnikov, L. Blondjo,F. Kjoberich, S. Yamaguchi, $S$. Tsumura and others researchers [3].

In accordance with the known concepts, in the presence of $\mathrm{SO}_{4}{ }^{2-}$ ions in the GBFS - water system ion exchange in the surface layer of the slag is intensified, the structure of the glassy phase of slags it is deformed, and needle crystals of calcium hydrosulfoaluminates are formed, which contributes to the strengthening of the solidifying mass. At the same time, the formation of low-basic calcium hydrosilicates occurs [4-7].

According to $[8,9]$, sulfate activation is most effective for high-alumina blast furnace slags, while alkaline is suitable for all types of slags. 
When studying the effect of various admixtures on the properties of SSC, it was found that various modifications of calcium sulfate $\left(\mathrm{CaSO}_{4} \times 2 \mathrm{H}_{2} \mathrm{O}\right.$, $\mathrm{CaSO}_{4} \times 0.5 \mathrm{H}_{2} \mathrm{O}$, insoluble or soluble anhydrite, phosphogypsum, etc.) can be used as activators of hydration processes, in the presence of a small amount alkalis or substances that release them (Portland cement clinker, burnt dolomite, lime) $[10,11]$.

The advantages of SSC, along with their low energy consumption and environmental attractiveness, are their increased resistance in sea, sulfate and soft water, relatively low heat generation, which is important for massive concrete. At the same time, SSC made using traditional technology are characterized by delayed hardening and relatively low strength.

The statement that for supersulfated cements it is necessary to use high-alumina blast-furnace granulated slag with an $\mathrm{Al}_{2} \mathrm{O}_{3}$ content of $10 \ldots 20 \%$ significantly limits the raw material base and possibilities of their production. Analysis of the known methods of production and use of SSC does not answer the question of the possibility of using various kinds of chemical admixtures - intensifiers, plasticizers and hardening accelerators[12,13].

The purpose of this work was to develop technological parameters for the production of SSC on the most common low-alumina blast-furnace granular slags $\left(\mathrm{Al}_{2} \mathrm{O}_{3}<10\right)$ with the study of the effect of the type of sulfate activators, as well as to determine the possibility of improving the properties (modification) of these cements with the addition of hardening accelerators and plasticizers.

\section{EXPERIMENTAL PART}

\section{Materials}

The studies were carried out using low-alumina granulated blast-furnace slag (GBFS) of the Krivoy Rog metallurgical plant (Ukraine). To study the sulfate activation of GBFS, used phosphogypsum, a by-product of the treatment of apatite concentrate with sulfuric acid in the preparation of orthophosphoric acid. As a result of long-term dump holding (more than 10 years), the content of water-soluble phosphates in the used phosphogypsum waste of the "Azot enterprise" (Rivne, Ukraine) did not exceed $0.15 \%$, the content of fluorides was $0.4 \%$. Phosphogypsum was neutralized with lime dried at $60 \ldots 80^{\circ} \mathrm{C}$. The specific surface area of phosphogypsum for various samples ranged from 260 to $330 \mathrm{~m}^{2} / \mathrm{kg}$. Electron microscopic analysis showed that it is represented by well-formed crystals of dihydrate gypsum with a length of $0.05 \ldots . .0 .2 \mathrm{~mm}$.

For comparison, gypsum stone (dihydrated gypsum) and hemihydrated gypsum (plaster of paris) were used as sulfate activators. The chemical composition of the starting components of the SSC is given in Table 1.

Table 1. Chemical composition of slag and sulfate activators

Tabela 1. Hemijski sastav šljake i sulfatnih aktivatora

\begin{tabular}{|c|c|c|c|c|c|c|c|c|c|}
\hline \multirow{2}{*}{ Type of material } & \multicolumn{9}{c|}{ Oxide content, \% } \\
\cline { 2 - 11 } & $\mathrm{SiO}_{2}$ & $\mathrm{Al}_{2} \mathrm{O}_{3}$ & $\mathrm{Fe}_{2} \mathrm{O}_{3}$ & $\mathrm{CaO}$ & $\mathrm{MgO}$ & $\mathrm{SO}_{3}$ & $\mathrm{MnO}_{2}$ & $\mathrm{P}_{2} \mathrm{O}_{5}$ & L.O.I. \\
\hline GBFS & 39,52 & 6,49 & 0,12 & 47,13 & 3,10 & 1,74 & 1,15 & - & - \\
\hline Phosphogypsum & - & 0,36 & 0,15 & 33,45 & 0,003 & 47,21 & - & 0,15 & 18,51 \\
\hline Gypsum stone & 2,21 & 0,32 & 0,15 & 33,32 & 0,21 & 45,52 & - & - & 19,35 \\
\hline Plaster of paris & 1,85 & 0,42 & 0,08 & 39,13 & 0,18 & 53,12 & - & - & 4,91 \\
\hline
\end{tabular}

In addition to the indicated gypsum materials, the effectiveness of water-soluble alkali metals sulfates $-\mathrm{Na}_{2} \mathrm{SO}_{4}$ and $\mathrm{K}_{2} \mathrm{SO}_{4}$ - as activators of GBFS was tested.

The possibility of modifying the properties of SSC was determined using also the addition of various hardening accelerators and plasticizers.

\section{Manufacturing and testing of the SSC}

Joint grinding of cement components was carried out in a laboratory ball mill to a specific surface $510 \ldots 530 \mathrm{~m}^{2} / \mathrm{kg}$. In addition to the sulfate activators, lime was introduced during grinding at of $1.5 \%$ in terms of $\mathrm{CaO}$.
To determine the strength parameters of the cement were used samples of $40 \times 40 \times 160 \mathrm{~mm}$ composition SSC: sand $=1: 3$. Along with the strength, the normal consistence and setting times of SSC were also determined. SSC tests are carried out in accordance with European norms EN 196-1: 2019 Cement test methods.

The combined effect of admixtures on the strength of cements $s$ was studied using mathematical planning of experiments [14] with subsequent analysis of the obtained adequate regression equations. 


\section{RESULTS AND DISCUSSION}

The comparative effect of various activators on the strength of the SSC is given in table.2. On the basis of preliminary experiments and stoichiometric calculations, from the condition of formation of hydrosulfoaluminates during SSC hardening, their content in the investigated compositions was taken to be $10 \%$ of the SSC mass.

Table 2. Influence of sulfate activators on the strength of SSC

Tabela 2. Uticaj sulfatnih aktivatora na jačinu SSC

\begin{tabular}{|c|c|c|c|c|}
\hline \multirow{2}{*}{ Activator type } & \multicolumn{2}{|c|}{ Flexural strength, MPa } & \multicolumn{2}{c|}{ Compressive strength, MPa } \\
\cline { 2 - 5 } & 7 day & 28 day & 7 day & 28 day \\
\hline Gypsum stone & 6,3 & 9,9 & 21,6 & 38,6 \\
\hline Phosphogypsum & 7,7 & 10,7 & 23,1 & 19,8 \\
\hline Plaster of paris & 2,7 & 6,4 & 12,6 & 13,2 \\
\hline $\mathrm{Na}_{2} \mathrm{SO}_{4}$ & 4,1 & 5,8 & 8,8 & 14,6 \\
\hline $\mathrm{K}_{2} \mathrm{SO}_{4}$ & 4,3 & 5,8 & 9,4 & \\
\hline
\end{tabular}

The data obtained indicate the greatest activating effect of phosphogypsum, which can be explained by its high reaction surface. The strength of SSC with the use of hemihydrated gupsum (plaster of paris) is almost in two times lower. Sulfates of alkali metals in terms of the magnitude of the activating effect turned out to be the least effective.

At the next stage of the research, the effect of fluoride salt admixtures on the strength of the SSC was determined.

In accordance with the known concepts, the $\mathrm{F}^{-}$ ion performs an activating effect in three directions [5]:

Table 3. Influence of fluoride admixtures on the strength of SSC

Tabela 3. Uticaj primesa fluorida na jačinu SSC

\begin{tabular}{|c|c|c|c|c|c|c|}
\hline \multicolumn{2}{|c|}{ Admixtures } & \multirow{2}{*}{$\begin{array}{c}\text { Water- cement } \\
\text { ratio }\end{array}$} & \multicolumn{2}{|c|}{ Flexural strength, MPa } & \multicolumn{3}{c|}{ Compressive strength, MPa } \\
\cline { 5 - 7 } & Content, $\%$ & 7 days & 28 days & 7 days & 28 days \\
\hline \begin{tabular}{c} 
View \\
\cline { 5 - 7 } \\
(control)
\end{tabular} & - & 0,4 & 9,3 & 10,4 & 29,5 & 36,4 \\
\hline $\mathrm{NaF}$ & 1,0 & 0,4 & 7,8 & 9,1 & 34,6 & 48,3 \\
\hline $\mathrm{NaF}$ & 2,0 & 0,4 & 8,4 & 9,9 & 35,2 & 49,2 \\
\hline $\mathrm{MgF}_{2}$ & 1,0 & 0,4 & 8,5 & 10,8 & 37,3 & 51,2 \\
\hline $\mathrm{MgF}_{2}$ & 2,0 & 0,4 & 9,2 & 11,8 & 37,9 & 52,3 \\
\hline $\mathrm{CaF}_{2}$ & 1,0 & 0,4 & 9,1 & 10,1 & 38,5 & 52,3 \\
\hline $\mathrm{CaF}_{2}$ & 2,0 & 0,4 & 10,2 & 10,5 & 38,1 & 53,4 \\
\hline $\mathrm{Na}_{2} \mathrm{SiF}_{6}$ & 1,0 & 0,4 & 9,2 & 12,5 & 37,9 & 55,7 \\
\hline $\mathrm{Na}_{2} \mathrm{SiF}_{6}$ & 2,0 & 0,4 & 10,2 & 11,7 & 39,2 & 57,2 \\
\hline
\end{tabular}

According to the data obtained, the use of $\mathrm{NaF}$ admixtures contribute to an increase in strength by $35 . . .40 \%$, and the addition of $\mathrm{MgF}_{2}$ and $\mathrm{CaF}_{2}$ made it possible to increase the strength by $42 \ldots 45 \%$. There is a certain increase in the strength of supersulfated cements with an increase in the molecular mass of the fluoride salt in the row:
- activates breaking of $\mathrm{SiO}$ - O bonds;

- replaces the $\mathrm{OH}$ group on the surface of the particles with $\mathrm{F}^{-}$;

- strengthens bonds during the formation of complexes $\mathrm{Ca}(\mathrm{OH})_{2}$ and $\mathrm{Si}(\mathrm{OH})_{2}$, strongly deforms the water molecule, promotes its dissociation and the formation of active ions $\mathrm{H}^{+}$ and $\mathrm{OH}^{-}$

The experiments were carried out using SSC obtained with phosphogypsum activator.

The results of studies of the activation of supersulfated cements with fluoride admixtures are presented in table 3 .
$\mathrm{NaF}<\mathrm{MgF}_{2}<\mathrm{CaF}_{2}<\mathrm{Na}_{2} \mathrm{SiF}_{6}$

An increase in the consumption of each of the admixtures from $1 \%$ to $2 \%$ does not entail a significant increase in strength; therefore, the consumption of an admixtures in an amount of $1 \%$ is sufficient (Fig. 1). 


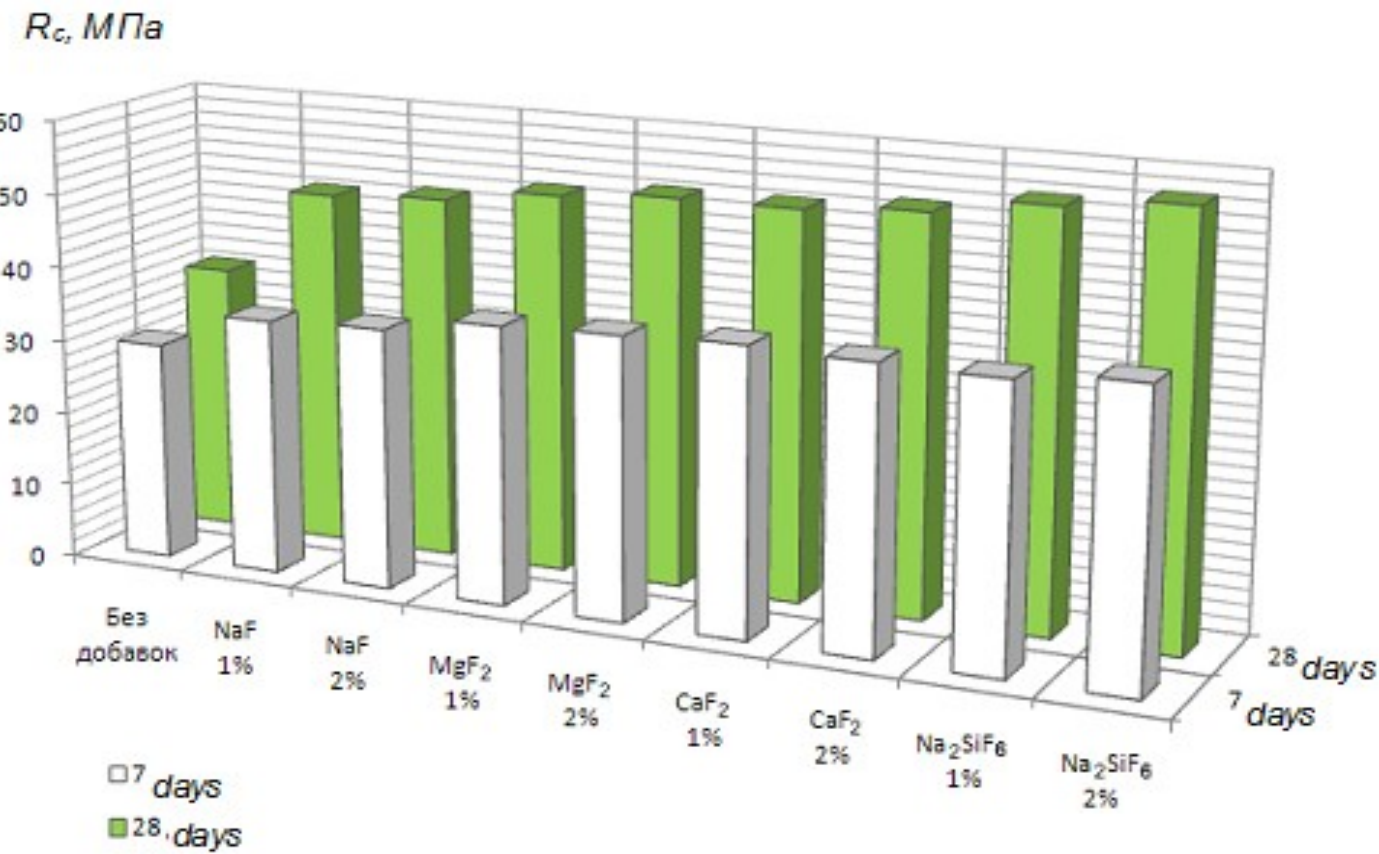

Figure 1. Influence of fluorides on the compressive strength of supersulfated cements

Slika 1. Uticaj fluorida na čvrstoću na pritisak supersulfatnih cementa

The strength of SSC with the addition of $\mathrm{Na}_{2} \mathrm{SiF}_{6}$ increased by almost $60 \%$ (Table 3) compared with the strength of the control composition. The stronger effect of $\mathrm{Na}_{2} \mathrm{SiF}_{6}$ on the strength of SSC, compared with the addition of
$\mathrm{NaF}, \mathrm{MgF}_{2}$ and $\mathrm{CaF}_{2}$, can be explained by the appearance of significant amounts of gel $\mathrm{Si}(\mathrm{OH})_{4}$ during hydrolysis of $\mathrm{Na}_{2} \mathrm{SiF}_{6}$ in water according to the reaction:

$$
\mathrm{Na}_{2} \mathrm{SiF}_{6}+4 \mathrm{H}_{2} \mathrm{O}=\mathrm{Si}(\mathrm{OH})_{4}+2 \mathrm{NaF}+4 \mathrm{HF}
$$

Table 4. Effect of hardening accelerators on strength supersulfated cements

Tabela 4. Uticaj akceleratora očvršćavanja na čvrstoću supersulfatnih cementa

\begin{tabular}{|c|c|c|c|c|c|c|c|c|}
\hline \multicolumn{2}{|l|}{ Admixture } & \multirow{2}{*}{$\begin{array}{c}\text { Water- } \\
\text { cement ratio }\end{array}$} & \multicolumn{3}{|c|}{ Flexural strength, $\mathrm{MPa}$} & \multicolumn{3}{|c|}{ Compressive strength, $\mathrm{MPa}$} \\
\hline Type of additive & Content, $\%$ & & 3 day & 7day & 28 day & 3day & 7 day & 28 day \\
\hline Without admixture (control) & - & 0,4 & 2,1 & 9,3 & 10,4 & 4,4 & 29,5 & 36,4 \\
\hline $\mathrm{Na}_{2} \mathrm{~S}_{2} \mathrm{O}_{3}$ & 1 & 0,4 & 4,6 & 9,9 & 10,9 & 11,9 & 23,5 & 39,8 \\
\hline $\mathrm{Na}_{2} \mathrm{~S}_{2} \mathrm{O}_{3}$ & 2 & 0,4 & 6,1 & 9,9 & 11,2 & 15,9 & 23,6 & 42,6 \\
\hline Relaxol-Temp & 1 & 0,4 & 8,5 & 10,8 & 9,9 & 24,3 & 36,7 & 51,2 \\
\hline Relaxol-Temp & 2 & 0,4 & 9,7 & 10,4 & 10,2 & 30,1 & 38,2 & 54,3 \\
\hline $\mathrm{Ca}\left(\mathrm{NO}_{3}\right)_{2}$ & 2 & 0,4 & 5,4 & 8,8 & 9,1 & 19,2 & 31,5 & 44,1 \\
\hline $\mathrm{Ca}\left(\mathrm{NO}_{3}\right)_{2}$ & 3 & 0,4 & 7,2 & 9,4 & 9,9 & 23,3 & 32,1 & 45,2 \\
\hline $\mathrm{CaCl}_{2}$ & 2 & 0,4 & 7,9 & 10,8 & 11,3 & 22,1 & 40,9 & 51,4 \\
\hline $\mathrm{CaCl}_{2}$ & 3 & 0,4 & 8,2 & 10,3 & 11,4 & 24,7 & 36,8 & 61,8 \\
\hline $\begin{array}{l}\text { Melflux-2561 } \\
+\mathrm{Ca}\left(\mathrm{NO}_{3}\right)_{2}\end{array}$ & $\begin{array}{c}0,4 \\
2\end{array}$ & 0,3 & 6,7 & 11,7 & 12,8 & 29,8 & 40,1 & 57,3 \\
\hline $\begin{array}{l}\text { Melflux-2561 } \\
+\mathrm{CaCl}_{2}\end{array}$ & $\begin{array}{c}0,4 \\
2\end{array}$ & 0,3 & 9,9 & 13,4 & 14,3 & 33,1 & 43,1 & 66,4 \\
\hline
\end{tabular}


The resulting gel actively interacts with cement and lime to form low-base hydrosilicates. Hydrofluoric acid HF is readily soluble in water (the concentration of aqueous solutions reaches more than $50 \%$ ) and interacts more actively with slag particles.

Along with the addition of fluorides, it was of interest to trace the effect on the strength of other admixtures known as hardening accelerators, as well as superplasticizers. Calcium chloride and nitrate, as well as sodium thiosulfate $\left(\mathrm{Na}_{2} \mathrm{~S}_{2} \mathrm{O}_{3}\right)$, were introduced in the amount of $1 \ldots 3 \%$ as accelerators of hardening. Polycarboxylate superplasticizer Melflux - 2561 served as a plasticizing admixture. The test results are shown in table 4.

The Relaxol-Temp hardening accelerator is a mixture of sodium thiosulfate and sodium rhodanide $\left(\mathrm{Na}_{2} \mathrm{~S}_{2} \mathrm{O}_{3}\right.$ and $\left.\mathrm{NaSCH}\right)$. Samples of SSC with this admixture in an amount of $1 . .2 \%$ (Table 4) gain strength on average 1.5 times faster than without a admixtures. At the same time, for SSC with the addition of only $\mathrm{Na}_{2} \mathrm{~S}_{2} \mathrm{O}_{3}$, an increase in strength by $1.2 \ldots 1.3$ times was noted compared to the control composition. An increase in the content of admixtures within $1 . . .2 \%$ gives a relatively small effect.

The hardening accelerator $\mathrm{Ca}\left(\mathrm{NO}_{3}\right)_{2}$ in an amount of $2 . .3 \%$ of the cement mass made it possible to achieve a certain increase in strength 1.2...1.25 times compared with the control composition, which is significantly less than when using such sulfur-containing soluble admixtures like $\mathrm{NaSCH}$ and Relaxol as well as $\mathrm{CaCl}_{2}$.

The introduction of $2 \% \quad \mathrm{CaCl}_{2}$ into the composition of SSC, even at $\mathrm{W} / \mathrm{C}=0.40$, made it possible to increase the strength of the cement above $51 \mathrm{MPa}$ at the age of 28 days. With an increase in $\mathrm{CaCl}_{2}$ consumption up to $3 \%$, the strength increased to values of more than $61 \mathrm{MPa}$. With joint action of $\mathrm{CaCl}_{2}(2 \%)$ and Melflux-2561 additives at $\mathrm{W} / \mathrm{C}=0.35$, the strength reached $\mathrm{a}$ value of more than $66 \mathrm{MPa}$. The complex use of $\mathrm{Ca}\left(\mathrm{NO}_{3}\right)_{2}$ and Melflux-2561 admixtures at $\mathrm{W} / \mathrm{C}=$ 0.35 gave a slightly smaller effect (55 MPa).

All of the above admixtures also affect the strength of SSC at the age of 3...7 days. Samples of the control composition (without admixtures) for the first three days of hardening gain a relatively low strength $-4 \mathrm{MPa}$, while during the first day the strength is insufficient even for stripping the samples. The use of the admixture of $\mathrm{Na}_{2} \mathrm{~S}_{2} \mathrm{O}_{3}$ also does not allow stripping after the 1 st day of hardening, but already on the 3rd and 7th days there is a noticeable significant acceleration of the hardening of SSC (Table 4). Relaxol-Temp, $\mathrm{Ca}\left(\mathrm{NO}_{3}\right)_{2}, \mathrm{CaCl}_{2}$ additives as well as composite admixtures Melflux-2561 $+\mathrm{Ca}\left(\mathrm{NO}_{3}\right)_{2}$ and Melflux$2561+\mathrm{CaCl}_{2}$ make it possible to achieve the stripping strength of specimens already after a day of hardening, and already on the 7th day the strength of SSC with these admixtures exceeds 30 MPa.

Table 5. Experiment planning conditions

Tabela 5. Uslovi planiranja eksperimenta

\begin{tabular}{|l|c|c|c|c|c|}
\hline \multicolumn{2}{|c|}{ Technological factors } & \multicolumn{3}{c|}{ Variation levels } & \multirow{2}{*}{ Variation interval } \\
\cline { 1 - 4 } Natural view & Coded view & -1 & 0 & +1 & 1,0 \\
\hline Lime content (on CaO), \% & x1 & 1,0 & 2,0 & 3,0 & 1,0 \\
\hline Supplement content CaCl2, \% & x2 & 0 & 1,0 & 2,0 & 1,0 \\
\hline Supplement content CaF2, \% & x3 & 0 & 1,0 & 2,0 & \multirow{2}{*}{} \\
\hline
\end{tabular}

The combined effect of the addition of the hardening accelerator $\mathrm{CaCl}_{2}$ and the activator $\mathrm{CaF}_{2}$ was investigated by performing algorithmic experiments in accordance with the standard plan $B_{3}$ [14]. The conditions for planning the experiment, the matrix and the research results are given in table 5 and 6 . On the basis of experimental data, the regression equations for the flexural and compressive strength of SSC at the age of 28 days were obtained. The values of water- cement ratio (W/C) in the experiments were determined from the condition of providing a standard spreading of the mortar cone. 
Table 6. Planning matrix and research results

Tabela 6. Matrica planiranja i rezultati istraživanja

\begin{tabular}{|c|c|c|c|c|}
\hline \multicolumn{3}{|c|}{ Factor coded values } & \multicolumn{2}{|c|}{ Ultimate of flexural $\left(R_{b}\right)$ and compressive $\left(R_{c}\right)$ strength, MPa } \\
\hline$x_{1}$ & $x_{2}$ & $x_{3}$ & $\mathrm{R}_{\mathrm{b}}$ & $\mathrm{R}_{\mathrm{c}}$ \\
\hline+1 & +1 & +1 & 11,5 & 59,4 \\
\hline+1 & +1 & -1 & 8,5 & 39,6 \\
\hline+1 & -1 & +1 & 8,9 & 40,6 \\
\hline+1 & -1 & -1 & 7,5 & 26,4 \\
\hline-1 & +1 & +1 & 9,6 & 43,3 \\
\hline-1 & +1 & -1 & 7,7 & 28,6 \\
\hline-1 & -1 & +1 & 7,8 & 29,2 \\
\hline-1 & -1 & -1 & 7,5 & 20,2 \\
\hline+1 & 0 & 0 & 9,9 & 50,2 \\
\hline-1 & 0 & 0 & 8,9 & 39,0 \\
\hline 0 & +1 & 0 & 10,0 & 51,1 \\
\hline 0 & -1 & 0 & 8,6 & 37,6 \\
\hline 0 & 0 & +1 & 10,1 & 51,0 \\
\hline 0 & 0 & -1 & 8,5 & 36,6 \\
\hline 0 & 0 & 0 & 9,7 & 48,4 \\
\hline 0 & 0 & 0 & 9,7 & 48,4 \\
\hline 0 & 0 & 0 & 9,7 & 48,4 \\
\hline
\end{tabular}

Table 7. Regression equations for the strength of a SSC with the addition of a hardening accelerator $\mathrm{CaCl}_{2}$ and an activator $\mathrm{CaF}_{2}$

Tabela 7. Regresione jednačine za čvrstoću SSC sa dodatkom akceleratora očvršćavanja $\mathrm{CaCl}_{2}$ aktivatora $\mathrm{CaF}_{2}$

\begin{tabular}{|l|c|}
\hline \multicolumn{1}{|c|}{ Initial parameters } & Regression equations \\
\hline Flexural strength at age, 28 days, $\mathrm{MPa}$ & $R_{b}^{28 \text { day }}=9,7+0,5 x_{1}+0,7 x_{2}+0,8 x_{3}-0,3 x_{1}^{2}-0,4 x_{2}^{2}-0,4 x_{3}^{2}$ \\
\hline $\begin{array}{l}\text { Compressive strength at the age of } 28 \text { days, } \\
\mathrm{MPa}\end{array}$ & $R_{c}^{28 \text { day }}=48,4+5,6 x_{1}+6,8 x_{2}+7,2 x_{3}-3,8 x_{1}^{2}-4,1 x_{2}^{2}-4,6 x_{3}^{2}$ \\
\hline
\end{tabular}

Analysis of the obtained regression equations (Table 7) and graphical dependencies (Fig.2 and 3) indicates that all three factors have a positive effect on the strength of supersulfated cements, that is, with an increase in their values, its strength increases, and by influence on strength, they can be arranged in the following row: $X_{3}>X_{2}>X_{1}$.

The influence of factors on strength is more pronounced precisely in the case of compressive strength; flexural strength changes relatively little. Graphical dependencies have an expressive parabolic character. The effect of activating slags by fluorides, which consists in activating the surface of its particles and thus increasing their reactivity, gives a more pronounced effect than the effect of increasing the concentration of $\mathrm{Ca}_{2}{ }^{+}$ions when using calcium chloride. 


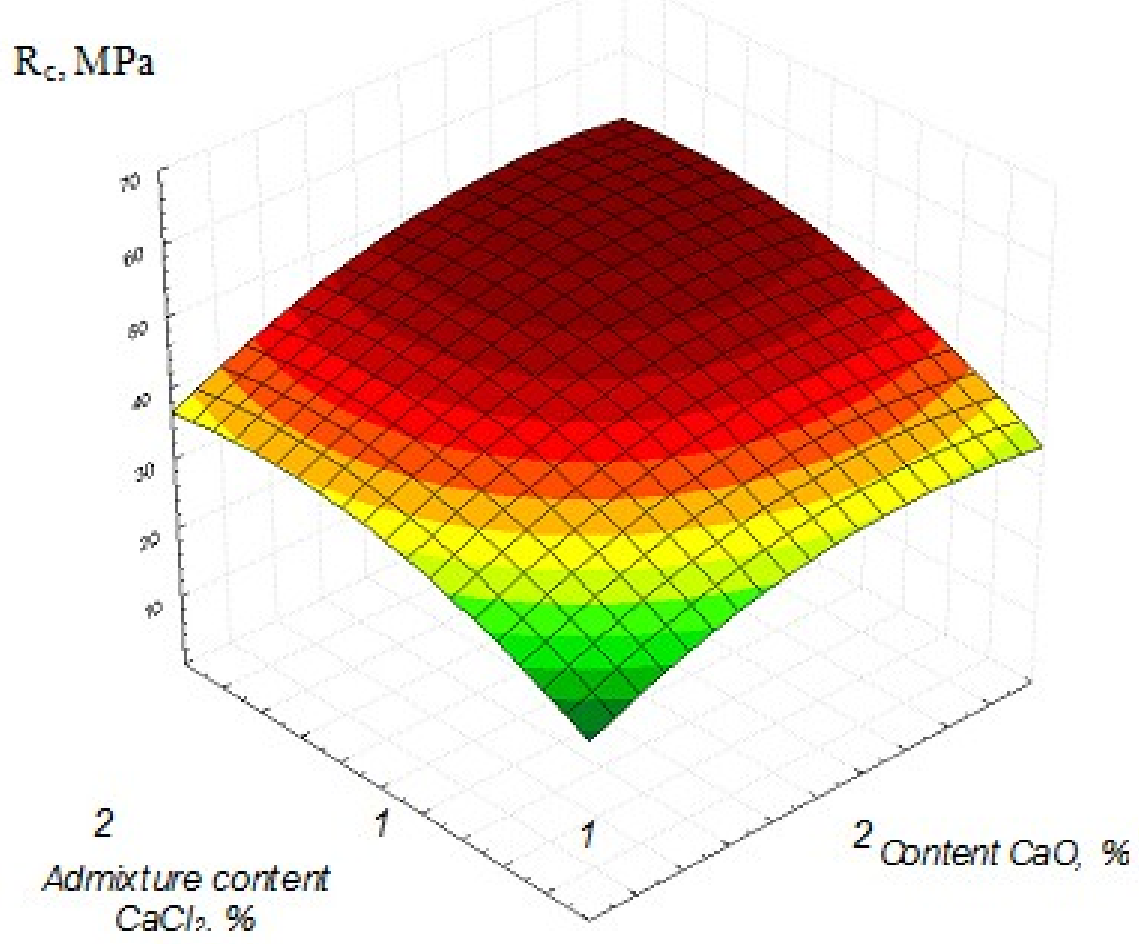

Figure 2. Dependences of the strength of SSC on the consumption of $\mathrm{CaCl}_{2}\left(x_{2}\right)$ and lime $\left(x_{1}\right)$, the content of the $\mathrm{CaF}_{2}$ additive $=1 \%\left(x_{3}=0\right.$

Slika 2. Zavisnosti jačine SSC od potrošnje $\mathrm{CaCl}_{2}\left(x_{2}\right)$ i kreča $\left(x_{1}\right)$, sadržaj aditiva $\mathrm{CaF}_{2}=1 \%\left(x_{3}=0\right)$

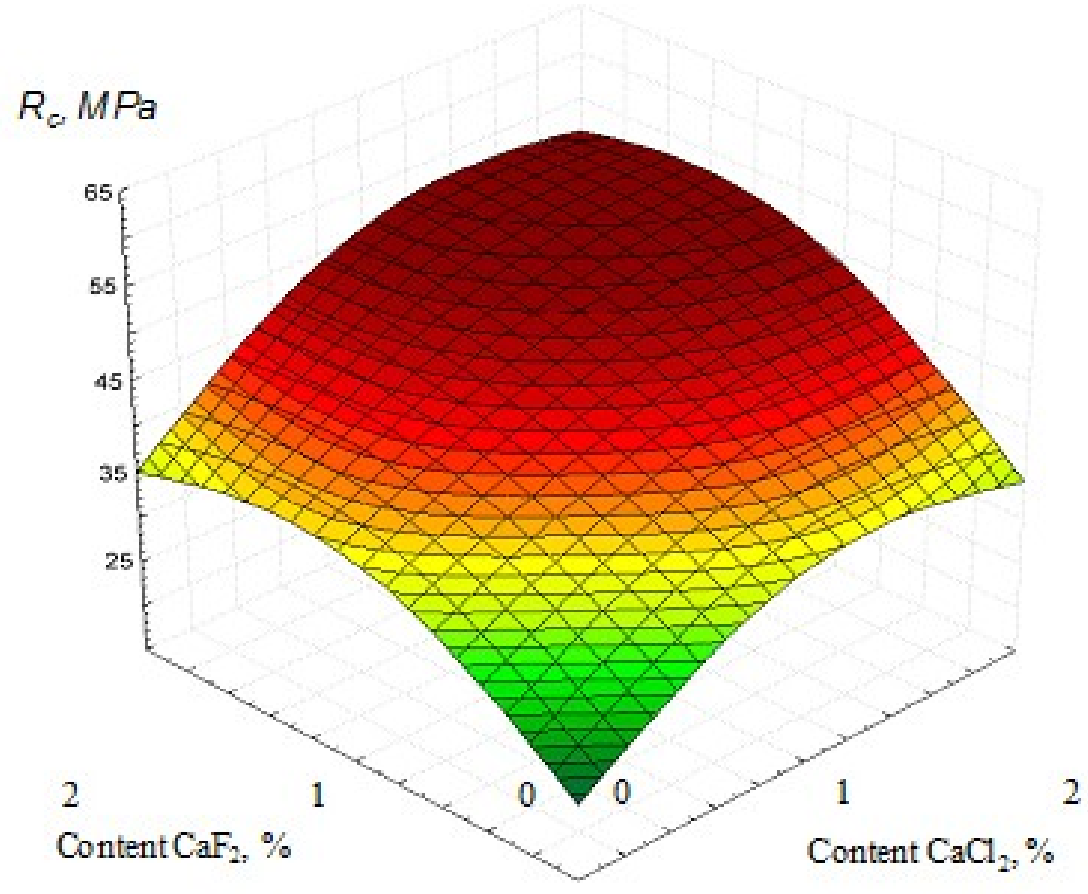

Figure 3. Dependences of the strength of SSC of $\mathrm{CaF}_{2}\left(x_{3}\right)$ and $\mathrm{CaCl}_{2}\left(x_{2}\right)$ additives consumption, lime content $1 \%\left(x_{3}=0\right)$

Slika 3. Zavisnosti jačine SSC od potrošnje aditiva $\mathrm{CaF}_{2}\left(x_{3}\right)$ i $\mathrm{CaCl}_{2}\left(x_{2}\right)$, sadržaj kreča $1 \%\left(x_{3}=0\right)$ 
Varying the lime content within $1 . . .3 \%$ have the least effect on the change in the strength of SSC. According to [15], the amount of lime within $1 \%$ is already sufficient for the SSC on the basic blast furnace slag. According to our data, the optimal lime content (in terms of $\mathrm{CaO}$ ) for used granulated blast furnace slag is $1.5 \%$. The maximum strength of supersulfated cements of this composition, according to the obtained dependences, reaches $60 \mathrm{MPa}$.

\section{CONCLUSIONS}

1. For the studied supersulfated cements from the tested sulfate activators, the best results were obtained using phosphogypsum.

The use of phosphogypsum as an activator allows, in comparison with gypsum stone and plaster of paris, to increase the compressive strength SSC in 7 days by 1.1-1.8 times; 28 days - 1.3-1.9 times. The activating effect of phosphogypsum is even more manifested in comparison with sodium and potassium sulfates.

2. An additional effect of activation of supersulfate cements is observed with the introduction of fluoride admixtures, of which the greatest increase in strength is provided by magnesium and calcium fluorides, as well as sodium silicofluoride.

3. The strength of supersulfate cements, including in the early dates, along with phosphate admixtures, can be significantly increased by the introduction of salts of hardening accelerators and superplasticizers.

At 28 days of age, the strength of SSC with the addition of hardening accelerators and their composition with a superplasticizer allows increasing the strength of cement by 1.5-2 times and lead to value it to 61-66 MPa.

4. A distinctive feature of the obtained results presented in the article is the established possibility of a significant improvement in the properties of supersulfate cements based on lowalumina blast-furnace granular slags with the introduction of a complex of effective sulfate and fluoride activators, admixtures of salts of hardening accelerators and superplasticizers.

\section{REFERENCES}

[1] F.Locher (2006) Cement. Principles of production and use, Verlag Bau+Technic, Dusseldorf.

[2] L.Dvorkin, O.Dvorkin (2011) Building mineral binders, Infra - Engineering, Moscow.

[3] H.Schwiete, U.Ludwig, P.Otto (1971) Investigations on super sulfated slag cements, West-dentscher Verl, Opladen.

[4] Q.Wu, Q.Xue, Z.Yu (2021) Research status of supersulfated cement, Journal of Cleaner Production, 294, 126-128.

[5] S.Stark (1999) Modern concrete materials: binders, addition and admixtures, Edh. Thomas Telford LTD. London.

[6] S.Bijen, E.Niel (1981) Supersulfated cement from blastfurnac slag and chemical gypsum available in the Netherlandes and neighbouring countries, Cem. Conc. Res, 11(3), 307-322.

[7] D.Gazdic (2013) Slag-Sulphate Binder, Preparation, Advanced Material Research, 818, 68-71.

[8] A.Volzhensky, M.Burov, V.Colokolnicov (1973) Mineral binders (Technology and properties), Stroyizdat, S-Peterburg.

[9] L.Svatovskya, M.Sychev (1983) Activated hardening of cements, S-Peterburg.

[10] V.Melhotra, A.Sai, P.Kapur (1982) Plaster of Paris activated sulfated slag cement, Cement and Concrete Research, 12 (4), 465-471.

[11] E.Erdem, H.Olmez (1993) The mechanical properties of Supersulfated cement containing phosphogypsum, Cem. Concr. Res., 23, 115-121.

[12] S.Reinsdorf (1962) Properties and utilization of supersulfated slag cement, Bauplan-Bautechn, 16(5), 230-234.

[13] H.Nquen, T.Chang, J.Shin, C.Chen (2016) Formulating for innovative Self-Compacting Concrete with Low Energy Super Sulfated Cement used for Sustainability Development, Journal of Material Science and Chemical Engineering. 4(7), 22-28.

[14] L.Dvorkin, O.Dvorkin, Y. Ribakov (2012) Mathematical Experiments in Concrete Technology, Nova Science Publishers, New York.

[15] A.Pashenko, P.Serbin, O.Starchevskya (1995) Binders substances, High School, Kiev. 


\section{IZVOD}

\section{MODIFIKOVANI SUPERSULFATNI CEMENTI}

U radu su prikazani rezultati eksperimentalnih istraživanja mogućnosti dobijanja modifikovanih supersulfatnih cementa (SSC) sa poboljšanim fizičko-mehaničkim svojstvima na niskoaluminijskim zrnastim šljakama visoke peći. U uporednim eksperimentalnim ispitivanjima dejstva primesa različitih sulfatnih aktivatora pokazano je da se najveća čvrstoća cementa postiže upotrebom fosfogipsa neutralisanog krečom.

Dodatno aktivirajuće dejstvo je utvrđeno za supersulfatne cemente sa uvođenjem dodataka fluorida i posebno fluorida magnezijuma, kalcijuma i natrijum silikofluorida. Dodatno uvođenje akceleratora očvršćavanja $i$ njihovih kompozicija sa superplastifikatorom u SSC sastav omogućava povećanje čvrstoće na pritisak cementa u starosti od 28 dana do 60-65 MPa uz postizanje visoke čvrstoće u ranom uzrastu.

Uporedo sa standardnim testovima, vršeni su eksperimenti primenom matematičkog planiranja uz dobijanje adekvatnih regresionih jednačina.

Ključne reči: šljaka visoke peći, sulfatni aktivatori, fosfogips, akceleratori očvršćavanja, superplastifikator, kreč, supersulfatni cement, svojstva.

Naučni rad

Rad primljen: 17. 09. 2021.

Rad prihvaćen: 29. 09. 2021.

Rad je dostupan na sajtu: www.idk.org.rs/casopis

(c) 2021 Authors. Published by Engineering Society for Corrosion. This article is an open access article distributed under the terms and conditions of the Creative Commons Attribution 4.0 International license (https://creativecommons.org/licenses/by/4.0/). 